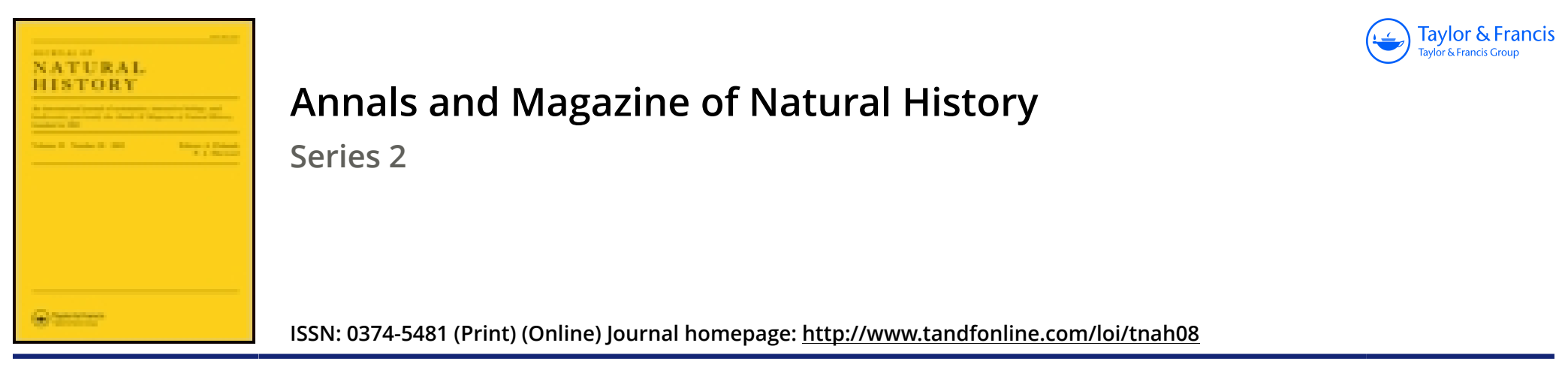

\title{
XXIX.-Notice on the question of the presence of an operculum in the genus Diplommatina, Benson, and description of a new species
}

\section{W.H. Benson Esq.}

To cite this article: W.H. Benson Esq. (1855) XXIX.-Notice on the question of the presence of an operculum in the genus Diplommatina, Benson, and description of a new species, Annals and Magazine of Natural History, 15:89, 329-331, DOI: 10.1080/037454809495434

To link to this article: http://dx.doi.org/10.1080/037454809495434

曲 Published online: 16 Dec 2009.

Submit your article to this journal $₫$

View related articles ¿ 
this, but the previously homogeneous internal substance of the chlorophyll-band is converted into a sort of frothy mass, like what may be so often observed in the protoplasm of cell-contents. The circumstance that the vesicles formed in this way are colourless or only weakly tinged (for this cannot be accurately made out), and break out from the interior of the chlorophyll-band, through its outer green layer, indicates that the substance of the band is not homogeneous, but that its internal substance especially attracts water, is softer, and more capable of extension than the external substance. These occurrences further tend to show that the green colouring matter is principally, if not exclusively, deposited in the outer layer; but this does not seem to me to be altogether certainly proved, since we cannot decidedly state what are the respective shares which the considerable mechanical expansion, and the original want of colour, bear in producing the colourless or lightly tinted condition of the vesicularly expanded internal substance; on this point the examination of a transverse section of a band could alone furnish a decided answer, but $I$ know of no means by which this could be obtained and observed in an unaltered condition. This much however is certain, that the green colour, if it does not uniformly permeate the whole substance, is still not restricted to a definitely bounded outer layer, since we should see this bounded, at the edge of the band, by a defined line.

[To be continued.]

XXIX.-Notice on the question of the presence of an Operculum in the genus Diplommatina, Benson, and description of a new Species. By W. H. Benson, Esq.

A Further reference to Capt. Hutton on the subject of the operculum of Diplommatina, since the publication of Dr. J. E. Gray's stricture in the July Number of the 'Annals' for 1853, just before my departure from England, having elicited no reply from my correspondent, I proceeded on the 17 th instant to a further examination by the gradual destruction of the lower whorls of several specimens of $D$. folliculus and costulata; which operation resulted in the detection of the operculum in both species, in which it was found to be withdrawn to a distance of from $1 \frac{1}{2}$ to 2 whorls and upwards from the aperture, so as to render its detection without that process impossible. Encouraged by this success, I have, since then, broken up a couple of specimens of $D$. Huttoni, Pfr., a reversed species, from Jerripani below Mussoorie, and one of my two specimens of a new sinistrorse Australian species, and have been equally successful with 
both, the opercula being similarly remote, and retained fully two whorls from the opening of the shells. I lose as little time as possible in acknowledging the correctness of Dr. Gray's reference of the genus to the Cyclostomacea, and in making known the discovery that my former opinion on the subject is untenable.

The expectation of finding the operculum at or near the aperture, induced by Dr. Gray's statement in a note dated in February 1853, that the operculum was "the usual external one, the size of the mouth of the shell," had caused me to stop short of the sacrifice of specimens in which no trace of the operculum could be perceived from the aperture; but the statement in his published note regarding its extreme minuteness created a suspicion that it might be found in a remote part of the shell, and this expectation was so fully borne out by experiment, that the unusual retraction of the accessory valve must be regarded as a generic character in Diplommatina; and if Dr. Gray's examples occurred within view from the aperture of unbroken specimens, we are authorized to conclude that the animals must have been suddenly killed, and prevented from retiring to their usual recondite position. The smallness of the operculum also explains why the tooth on the internal part of the columella affords no obstacle to the passage of the valve to the remoter whorls, and why no modification of its circular form is necessary for the execution of that movement, in spite of the apparent obstruction presented.

Dr. Gray correctly reminds us that "the operculum of Acme fusca was overlooked by many malacologists, and has been denied after it was described by others, as is the case with that of $D i$ plommatina ;" for, in the list of those who contested its existence in Acme, we find the honoured name of De Férussac, and at as late a date as that of the publication of Gray's edition of 'Turton's Manual *,' the now patent fact was opposed, and the shell was classed, like Diplommatina, with Carychium, instead of with its real ally, Cyclostoma elegans; so that the supporters of the Carychiadous affinity of Diplommatina have erred in good company-

“- veniam damus petimusque vicissim."

The fact seems to be, that in these minute shells the exceeding delicacy of the transparent operculum eauses its concealment, during life, by the mucus of the animal, and it is not until this has dried up, and become more or less separated from the hard covering, that the latter becomes visible: in $A$. fusca it remains in the mouth of the shell, but being so much smaller than the

* Edition of 1840 . 
aperture in Diplommatina, it is drawn to a greater distance than in any other known operculated land mollusk. This habit also accounts for the absence of loose opercula in the boxes in which specimens have been kept, as observed by Capt. Hutton and myself ; the valve is drawn tightly into the narrower whorls, and there remains a fixture, as long as the lower whorls are preserved entire.

It is worthy of note that, in September 1849, Professor Albert Mousson of Zürich wrote as follows, when acknowledging specimens which I had sent to him:- "En examinant bien attentivement l'ouverture de votre Diplommatina folliculus, garnie d'un bord entier, et la costulation extérieure, on est frappé de la ressemblance avec le genre Pomatias, Stud. Veuillez bien en parcourir un plus grand nombre et vous assurer s'il ne s'en trouve pas quelques individus munis encore de leur opercule en parchemin." His prognostication has proved tolerably correct.

It is desirable that some collector possessing the doubtful Philippine shell, Cyclostoma minus, Sow. (D. Sowerbyi, Pfr.), should devote a specimen to a search for the operculum, which, if the species really belongs to Diplommatina, will doubtless be found in its ordinary retracted position, when its structure will decide the question.

\section{Diplommatina Australia, nobis.}

Testa sinistrorsa, rimata, subovato-conica, glabra, subremote-costata, pallide cornea, spira ovato-conica, apice acutiusculo; anfractibus sex convexis, ultimo angustiore, antice ascendente; apertura verticali, subcirculari, peristomate duplice, posteriori expanso, anteriori expansiusculo, marginibus nitidis, diaphanis, callo junctis, exteriori superne breviter producto, columellari dilatato, tuberculo inconspicuo vel obsoleto. Operculo remoto, normali, lamella vix elevata.

Long. $3 \frac{1}{2}$, diam. vix 2 mill.

Hab. ad Mount Warren, Point Danger, Australiæ Orientalis. Teste Strange.

About the same size as $D$. folliculus, $\mathrm{Pfr}$., it is less acuminate, and may at once be known by its sinistrorse volutions, more distant costulation, and by the produced portion of the outer lip near its junction with the body whorl. The operculum occurs at the distance of two whorls from the aperture. Mr. Strange told me that he had found it under dead leaves in the brushes. The occurrence of the genus at such a distant point, in a southern latitude, from its Himalayan head-quarters, is an interesting fact. Perhaps diligent search on decayed leaves, in damp situations, may reveal other species in the intervening lands.

Nice Maritime, 22nd March 1855. 